\title{
Expression and mechanism of PinX1 and telomerase activity in the carcinogenesis of esophageal epithelial cells
}

\author{
JING ZUO $^{1 *}$, DA-HU WANG ${ }^{2 *}$, YU-JUN ZHANG ${ }^{3}$, LIANG LIU $^{4}$, FENG-LING LIU ${ }^{1}$ and WEI LIU ${ }^{1}$ \\ ${ }^{1}$ Department of Oncology, the Fourth Hospital of Hebei Medical University, Shijiazhuang, Hebei 050012; \\ ${ }^{2}$ Department of Dermatology, the Second Hospital of Hebei Medical University, Shijiazhuang, Hebei 050000; \\ ${ }^{3}$ Department of Pathology, Shijiazhuang People's Medical College, Shijiazhuang, Hebei 050091; \\ ${ }^{4}$ Hebei Cancer Institute, Hebei Medical University, Shijiazhuang, Hebei 050011, P.R. China
}

Received April 26, 2013; Accepted June 19, 2013

DOI: $10.3892 / o r .2013 .2649$

\begin{abstract}
Esophageal tissues were collected from an esophageal carcinoma high-risk area of China and were used to detect the telomere length and the expression of human telomerase reverse transcriptase (hTERT) by immuhistochemistry and fluorescence in situ hybridization; esophageal carcinoma tissues, paired-adjacent mucosa and paired normal mucosa were obtained from resected surgical specimens of esophageal squamous cell carcinoma in order to determine telomerase activity and expression of hTERT and Pin2/TRF1 interacting protein $\mathrm{X} 1$ (PinX1) by telomeric repeat amplification protocol-silver staining, RT-PCR and flow cytometry (FCM). The cell proliferation and apoptosis of Eca109 cells were analyzed by FCM and MTT assay. We found that the length of telomere DNA decreased and hTERT protein expression increased in the carcinogenesis of esophageal epithelial cells; telomerase activity was significantly upregulated followed by a decrease of PinX1 expression in esophageal carcinoma compared with dysplasia and normal patients, which notably correlated with grade and lymph node metastasis. Overexpression of PinX1 inhibited cell growth, arrested cells at the G0/G1 stage and induced cell apoptosis in Eca109 cells. In addition, PinX1 overexpression significantly inhibited telomerase activity. In conclusion, the length shortening of telomere was an important characteristic in the carcinogenesis of esophageal epithelial cells, followed by increase of telomerase activity and downregulation of PinX1. Overexpression of PinX1 blocked Eca109 cell proliferation and induced cell apoptosis by downregulating telomerase activity.
\end{abstract}

Correspondence to: Professor Wei Liu, Department of Oncology, the Fourth Hospital of Hebei Medical University, 12 Jiankang Road, Shijiazhuang, Hebei 050012, P.R. China

E-mail: liuweihebei@yahoo.com

${ }^{*}$ Contributed equally

Key words: esophageal carcinoma, telomerase activity, Pin2/TRF1 interacting protein $\mathrm{X} 1$, human telomerase reverse transcriptase, apoptosis

\section{Introduction}

Esophageal carcinoma is one of the most common malignant gastrointestinal tumors with a high incidence in China and is characterized by a unique geographical distribution. Therefore, it is necessary to elucidate the underlying mechanisms and to search for chemopreventive tools or drugs to decrease the risk of carcinogenesis of esophageal epithelial cells.

Studies have indicated that maintenance of telomere length is important in preventing the consumption of telomere DNA during cell division. Studies found significant associations between short telomere length and increased esophageal cancer risk $(1,2)$.

Telomerase is a ribonucleoprotein enzyme complex that adds 5'-TTAGGG-3' repeats onto the ends of human chromosomes, providing a telomere maintenance mechanism for $\sim 90 \%$ of cancers (3). Telomerase consists of several subunits, including hTERC that serves as a template during telomere elongation and a catalytic subunit, human telomerase reverse transcriptase (hTERT), which has reverse transcriptase activity. Moreover, telomerase activity is dependent on the expression of 2 main core component genes, hTERT and hTERC. This has prompted a large number of studies addressing telomerase activity using telomeric repeat amplification protocol (TRAP) assay $(4,5)$, amplification of hTERC using in situ hybridization (6-11) or expression of hTERT using immunohistochemistry (IHC) in cervical cancer and cervical intraepithelial neoplasia lesions (12-14), which indicated that the telomerase activation mediated tumor cell growth.

Studies have shown that inhibition of telomerase results in gradual erosion of telomeres followed by cessation of proliferation or apoptosis, and may thus be a promising target for cancer therapy. Pin2/TRF1 interacting protein X1 (PinX1) was previously found to be a tumor suppressor and telomerase inhibitor in vivo. It is expressed in normal human tissues, but is not, or is less, expressed in tumor tissues. Studies have found that PinX1 can inhibit telomerase activity in gastric and liver tumor cells and can induce apoptosis (15-18). In addition, the expression of PinX1 has been positively correlated with telomerase activity in leukemia $(19,20)$. However, some studies on prostate cancer, gastrointestinal cancer and medulloblastoma indicate that gene polymorphism rather than PinX1 expression 
is the key factor in inhibiting telomerase (21-23) and PinX1 as a microtubule binding protein plays an important role in stabilizing chromosome (24). In short, the mechanisms by which PinX1 regulates telomerase/telomere in tumor cells are complex and may vary in different tumors. The effect of PinX1 on esophageal carcinoma cell proliferation and the mechanisms by which PinX1 affects telomerase activity have yet to be reported. Therefore, in the present study, we detected the expression of PinX1 and telomerase activity in esophageal squamous cell carcinoma (ESCC), dysplasia of esophageal squamous epithelium and normal esophageal mucosa in order to explore the relationship with carcinogenesis of esophageal epithelium; moreover, we created Eca109 stable cell lines overexpressing PinX1 to investigate the effects of PinX1 on the telomerase activity and cell proliferation, apoptosis, and further explored the possible mechanism of PinX1-mediated carcinogenesis of esophageal epithelial cells.

\section{Materials and methods}

Reagents and antibodies. TRIzol reagent and Lipofectamine ${ }^{\circledR}$ 2000 were obtained from Invitrogen (Carlsbad, CA, USA). Horseradish peroxidase (HRP) AffiniPure goat anti-mouse/ rabbit $\operatorname{IgG}(\mathrm{H}+\mathrm{L})$ was purchased from Zhongshan Golden Bridge Biotechnology Co., Ltd. (Beijing, China). FITC AffiniPure goat anti-mouse IgG was from Jackson ImmunoResearch. Telomere RNA probe kit was from (Dako, USA) and Telomerase activity kit from Jermaine gene Co., (USA). pCDNA3.1 vector and pCDNA3.1/PinX1 were obtained from Invitrogen. Geneticin ${ }^{\circledR}$ (G418) was from Gibco (USA). The mouse anti-hTERT and mouse anti-PinX1 antibodies were from Santa Cruz Biotechnology, Inc. (Santa Cruz, CA, USA).

Clinical materials. One-thousand cases of esophageal tissues from patients without chemotherapy and radiotherapy were collected from an esophageal carcinoma high-risk area of China. All specimens were verified by pathologic diagnosis and we selected 44 cases of ESCC, 50 dysplasia of esophageal squamous epithelium (22 cases of mild dysplasia and 28 cases of severe dysplasia) and 36 normal esophageal mucosa to be used to detect the length of telomere and hTERT protein expression.

Moreover, esophageal carcinoma tissues, paired adjacent mucosa (2-5 cm from margin of esophageal carcinoma) and paired normal mucosa (at least $5 \mathrm{~cm}$ from margin of esophageal carcinoma) were obtained from resected surgical specimens of ESCC. All specimens were verified by pathologic diagnosis, 50 cases of ESCC, dysplasia of esophageal squamous epithelium and normal esophageal mucosa were selected from 130 specimens. Fifty ESCC tissues included 39 cases of well and moderately differentiated ESCC and 11 cases of poorly differentiated ESCC; fibrous membrane invasion $(n=34)$, fibrous membrane untouched $(n=16)$; lymph node metastasis positive $(n=17)$, lymph node metastasis negative $(n=33)$. Experimental protocols were approved by the Institutional Human Care and Use Committee of Hebei Medical University.

Cell lines. Human esophageal cancer cells (Eca109) were grown under humidified air with $5 \% \mathrm{CO}_{2}$ in an incubator at $37^{\circ} \mathrm{C}$ in RPMI-1640 supplemented with $10 \%$ fetal bovine serum, $100 \mu \mathrm{g} / \mathrm{ml}$ streptomycin and $100 \mathrm{U} / \mathrm{ml}$ penicillin.
Fluorescence in situ hybridization (FISH) for telomere length. The single cell suspension was acquired as previously described and incubated with FITC-(CCCTAA)3PNA probe for $15 \mathrm{~min}$ at $87^{\circ} \mathrm{C}$. Then, after overnight hybridization at room temperature, the cell suspensions were washed, followed by staining with propidium iodide (PI) solution for $2 \mathrm{~h}$ at $4^{\circ} \mathrm{C}$. Subsequently, the cells were analyzed in an Epics-XL II Flow Cytometer (Beckman Coulter, Miami, FL, USA). Q-FISH was used to represent the telomere length. Q-FISH = fluorescence intensity in experimental group - fluorescence intensity in background group.

IHC for detection of $h$-TERT protein. The tissues were fixed in $4 \%$ formaldehyde. Antigen recovery was performed using a microwave. The sections were incubated with primary antibodies against hTERT $(1: 100)$ overnight at $4^{\circ} \mathrm{C}$. The following day, the sections were incubated with polyperoxidase-antimouse IgG at $37^{\circ} \mathrm{C}$ and finally stained with diaminobenzidine. The sections were imaged with an Olympus microscope. Positive staining of hTERT protein was located in the nuclei of epithelial cells. The result criteria: the number of positive cells was $>10 \%$.

Measurement of hTERT and PinX1 protein by FCM analysis. The tissues in different groups were washed with phosphate buffered saline (PBS), fixed in $70 \%$ ethanol, and the single cell suspensions were then collected and washed with PBS, stained with mouse anti-hTERT or PinX1 antibodies at room temperature for $30 \mathrm{~min}$. Then, the cells were washed 3 times with PBS and incubated with FITC-anti-mouse $\operatorname{IgG}$ at $37^{\circ} \mathrm{C}$. The stained cells were analyzed in an Epics-XL II Flow Cytometer. Fluorescence index (FI) represents the relative protein expression content. FI = (fluorescence intensity in experimental group - fluorescence intensity in control group)/fluorescence intensity in normal control.

TRAP-silver stain for quantification of telomerase activity. Biopsy samples were stored in liquid nitrogen. The extraction of telomerase protein and evaluation of its activity were measured by the TRAP method using the TRAPeze-XL Telomerase Detection kit as previously described (12). Briefly, extracts from $100 \mathrm{mg}$ of frozen esophageal tissues were homogenized in $200 \mu \mathrm{l}$ of lysis buffer. After $30 \mathrm{~min}$ of incubation on ice, the suspensions were centrifuged at $16,000 \mathrm{x} \mathrm{g}$ for $30 \mathrm{~min}$ at $4^{\circ} \mathrm{C}$, after which the supernatant was frozen rapidly and stored at $-70^{\circ} \mathrm{C}$. The PCR conditions were: after $10 \mathrm{~min}$ for telomerase extension at $23^{\circ} \mathrm{C}, 95^{\circ} \mathrm{C}$ for $5 \mathrm{~min}$ to activate the Taq polymerase; 27 cycles at $94^{\circ} \mathrm{C}$ for $30 \mathrm{sec}, 50^{\circ} \mathrm{C}$ for $30 \mathrm{sec}$, and $72^{\circ} \mathrm{C}$ for $90 \mathrm{sec}$; an extension at $72^{\circ} \mathrm{C}$ for $10 \mathrm{~min}$; finally, a $4^{\circ} \mathrm{C}$ incubation. Equal amounts of amplified products were separated by $12 \%$ sodium dodecyl sulfate-polyacrylamide gel electrophoresis (SDS-PAGE). The gel was stained with $2 \%$ silver nitrate cream for $20 \mathrm{~min}$ after fixing with DNA fixative solution. After washing twice with d.d. water, the gel was placed in medium of $1.5 \% \mathrm{NaOH}$ and $0.4 \%$ formaldehyde and waved lightly until clear DNA ladder appeared.

RNA isolation and measurement of PinX1 mRNA by RT-PCR. Total RNA was extracted from esophageal tissues or Eca109 cells with TRIzol reagent according to the manufacturer's 
Table I. Length of telomere DNA in various lesions of esophageal epithelial cells by FCM (mean \pm standard variation).

Telomere length, $\mathrm{n}(\%)$

\begin{tabular}{lccccr}
\cline { 4 - 5 } Group & $\mathrm{n}$ & Q-FISH & Extend $^{\mathrm{a}}$ & Shorten $^{\mathrm{b}}$ & Normal $^{\mathrm{b}}$ \\
\hline Normal & 36 & $50.83 \pm 8.86$ & & & \\
Mild dysplasia & 22 & $49.51 \pm 3.16$ & $2(9.09)$ & $13(59.09)$ & $7(31.82)$ \\
Severe dysplasia & 28 & $36.96 \pm 8.02^{\mathrm{a}}$ & $2(7.14)$ & $20(71.43)^{\mathrm{a}}$ & $6(21.43)$ \\
Carcinoma & 44 & $27.80 \pm 6.59^{\mathrm{b}}$ & $3(6.82)$ & $35(88.64)^{\mathrm{b}}$ & $6(13.64)$
\end{tabular}

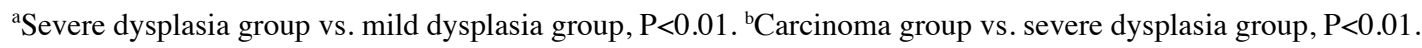

instructions. Total RNA ( $2 \mu \mathrm{g})$ was reverse transcribed into cDNA by AMV reverse transcriptase at $42^{\circ} \mathrm{C}$ for $1 \mathrm{~h}$ and then heated to $94^{\circ} \mathrm{C}$ for $5 \mathrm{~min}$ in a total reaction volume of $20 \mu \mathrm{l}$. PCR conditions used for PinX1 and internal reference GAPDH were: $94^{\circ} \mathrm{C}$ for $2 \mathrm{~min}$ followed by 30 cycles of $94^{\circ} \mathrm{C}$ for $30 \mathrm{sec}$, $55^{\circ} \mathrm{C}$ for $30 \mathrm{sec}$ and $72^{\circ} \mathrm{C}$ for $30 \mathrm{sec}$, and $72^{\circ} \mathrm{C}$ for $5 \mathrm{~min}$. The specific primers were: PinX1 forward, 5'-CCTCAGAACA CTGCCTGGAG-3' and reverse, 5'-GTTCCACCTGCGTCT CAGAA-3'; GAPDH forward, 5'-CCTGAGGGTTCTTTGT GCTGA-3' and reverse, 5'-AAAGGCTCAACCTTCCCCAT-3'. The expected PCR products were $577 \mathrm{bp}$ and $122 \mathrm{bp}$ for PinX1 and GAPDH, respectively. The amplicons were analyzed by electrophoresis, imaged using UVI gel imaging system and quantified using Gel-proAnalyzer3.1 software. Expression levels of PinX1 were normalized to internal reference GAPDH.

Cell culture and preparation of stable Ecal09 cell lines overexpressing PinX1. Stable transfections of Eca109 cells with pCDNA3.1 vector and pCDNA3.1/PinX1 were performed with Lipofectamine ${ }^{\circledR} 2000$, according to the manufacturer's instructions. Subsequently, cells were cultured in selection medium containing $0.5 \mathrm{mg} / \mathrm{ml} \mathrm{Geneticin}{ }^{\circledR}$ (G418) for 4 weeks before single clones were isolated. The clones were further expanded in selection medium containing Geneticin $(0.5 \mathrm{mg} / \mathrm{ml})$. Untransfected cells and cells transfected with pCDNA3.1 were used as controls. Cells were observed 24-48 h after transfection under a fluorescence microscope to examine transfection efficiency.

Detection of PinX1 protein by western blot analysis. Total protein extraction from cultured Eca109 cells was performed as previously described (25). Protein was quantified with a Bio-Rad Protein Colorimetric Assay (Bio-Rad, Hercules, CA, USA). Equal amounts of protein extracts were separated by $10 \%$ SDS-PAGE and transferred to polyvinylidene difluoride membranes (Millipore Corp., Billerica, MA, USA) as previously described (26). The concentration of anti-PinX1 antibody and anti- $\beta$-actin antibody was $1: 100$ (41 kDa) and 1:1,000(42 kDa), respectively. PinX1 protein expression was quantified by comparison with $\beta$-actin.

Measurement of cell proliferation by MTT. Eca109 cells at the logarithmic phase were inoculated into 96 -well plates with $1 \times 10^{5}$ cells/well. Cell viability at $24 \mathrm{~h}$ was examined using the MTT method. OD $_{490 \mathrm{~nm}}$ values were detected in 6 duplicate wells and their averages were used to plot growth curve and calculate the growth inhibition rate of each treatment using the following formula: Growth inhibition rate $\mathrm{Ir}=\mathrm{OD}_{490 \mathrm{~nm}}$ of the control group - $\mathrm{OD}_{490 \mathrm{~nm}}$ of the treatment group/OD $\mathrm{OD}_{490 \mathrm{~nm}}$ of the control group x $100 \%$.

Measurement of cell cycle and apoptosis by flow cytometry. Forty-eight hours after transfection, Eca109 cells were collected, washed with PBS, resuspended in PBS at $1 \times 10^{6} / \mathrm{ml}$, and stained with Annexin V and PI for $15 \mathrm{~min}$ in the dark. Apoptotic cells were then analyzed by flow cytometry and apoptotic index (AI) was calculated using $\mathrm{AI}=$ apoptotic cells/total cells $\mathrm{x} 100 \%$. Cell cycle was determined after fixing with precooled $75 \%$ ethanol at $4^{\circ} \mathrm{C}$ and washing with PBS.

Statistical analysis. Data are expressed as mean \pm standard variation and analyzed using SPSS 13.0 statistical software package. Differences between samples were tested using single factor analysis of variance and LSD method for multiple comparisons. A P-value $<0.05$ was considered to indicate a statistically significant difference. Prior to the comparison, data homogeneity of variance was first examined using F-test. In the case of heterogeneity of variance, the approximate variance F-test/Welch method was used.

\section{Results}

Decrease of length of telomere DNA and increase of hTERT protein in the carcinogenesis of esophageal epithelial cells. Value of Q-FISH was analyzed by FCM assay in the normal esophageal epithelium group, the mild dysplasia group, the severe dysplasia group and the carcinoma group. Q-FISH in the carcinoma group was lower than in the severe dysplasia group $(\mathrm{P}<0.01)$, but it was lower in the severe dysplasia group than in the mild dysplasia group $(\mathrm{P}<0.01$, Table I). There was a negative correlation between telomere length and cytologic grade in esophageal cancer $(\mathrm{r}=-0.79, \mathrm{P}<0.01)$. As shown in Table I, the shorten rate of telomere length in the carcinoma group was higher compared with that in the mild dysplasia and severe dysplasia group.

The positive expression of hTERT protein was located in the nucleus of esophageal epithelial cells and cancerous cells by immunohistochemical staining (Fig. 1A). The positive rate of hTERT in incisal margin normal tissue was $11.1 \%(4 / 36)$ and those in para-tumorous dysplasia tissues and carcinoma were 
A

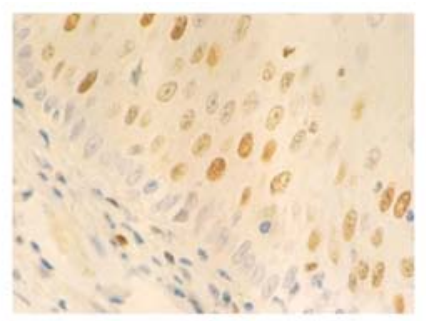

dysplasia group

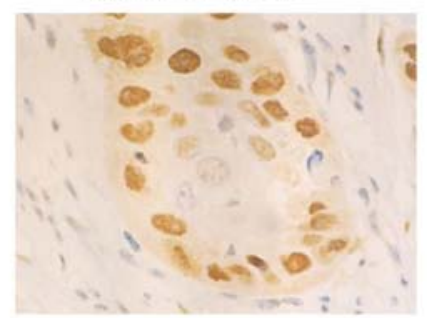

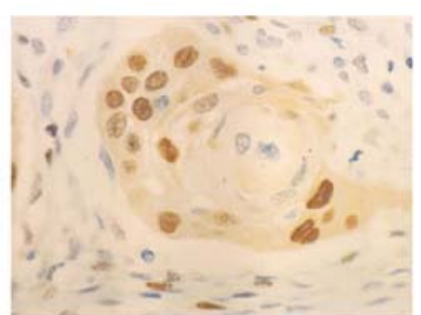

well differentiated carcinoma



moderately differentiated carcinoma poorly differentiated carcinoma

B
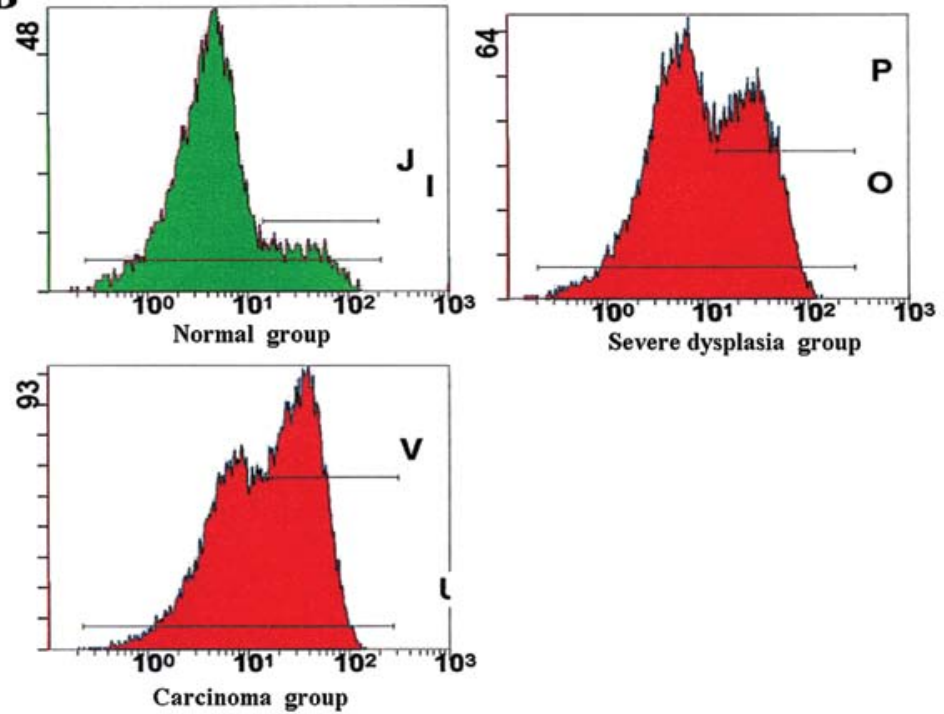

Figure 1. Upregulation of human telomerase reverse transcriptase (hTERT) protein in the carcinogenesis of esophageal epithelial cells. (A) Immunohistochemical staining for hTERT protein, positive expression located in the nuclei of epithelial cells. (B) Using FCM, the hTERT protein increased in the carcinoma group compared with the severe dysplasia and normal group.

$44.0 \%(22 / 50)$ and $86.37 \%(38 / 44)$, the positive expression rate increased gradually with carcinogenesis of esophageal epithelial cells $(\mathrm{P}<0.01)$.

FI value of hTERT in the normal esophageal epithelium group, mild dysplasia group, severe dysplasia group and carcinoma group was $0.87 \pm 0.18,1.13 \pm 0.19,1.39 \pm 0.24$ and $1.84 \pm 0.21$ (Table II) (Fig. 1B). FI value of hTERT in the carcinoma group was higher than in the severe dysplasia group $(\mathrm{P}<0.01)$, and it was higher in the severe dysplasia group than in the mild dysplasia group $(\mathrm{P}<0.01)$. In addition, FI value of hTERT was positively related with cytologic grade $(r=0.84, \mathrm{P}<0.01)$.

There was a negative correlation between Q-FISH value of telomere and FI value of hTERT $(\mathrm{r}=-7.49, \mathrm{P}<0.01)$.

Increase of telomerase activity and decrease of PinX1 in the carcinogenesis of esophageal epithelial cells. The telomerase activity in different histological groups is summarized in
Table III. The levels of telomerase activity were $0.073 \pm 0.039$ in the normal group, $0.429 \pm 0.346$ in the dysplasia group, $1.457 \pm 0.838$ in the carcinoma group. Telomerase activity was higher in the carcinoma group compared to the control normal or dysplasia group $(\mathrm{P}=0.00)$. Moreover, the A-value of telomerase activity was related to the tumor tissue grade and lymph node metastasis $(\mathrm{P}<0.05)$, but not to other clinicopathological features in ESCCs ( $P>0.05$, Table IV).

The results of RT-PCR showed that the relative expression of PinX1 mRNA in esophageal cancer tissues was significantly lower than that in normal tissues and dysplasia esophageal tissues $(\mathrm{P}<0.01)$ (Fig. 2A). As shown in Fig. 2B, the PinX1 protein level in esophageal cancer tissues was significantly lower than in the dysplasia and normal group, and there was a negative correlation with differentiation, invasive depth and lymph node metastasis $(\mathrm{P}<0.05$, Table $\mathrm{V})$ and no correlation with age and gender in ESCCs $(\mathrm{P}>0.05$, Table $\mathrm{V})$. 
Table II. Content of hTERT protein in various lesions of esophageal epithelial cells by FCM (mean \pm standard variation).

\begin{tabular}{lcccc}
\hline Group & $\mathrm{n}$ & hTERT FI & F & P-value \\
\hline Normal & 36 & $0.87 \pm 0.18$ & 73.52 & $<0.01$ \\
Mild dysplasia & 22 & $1.13 \pm 0.19$ & & \\
Severe dysplasia & 28 & $1.39 \pm 0.24^{\mathrm{a}}$ & & \\
Carcinoma & 44 & $1.84 \pm 0.21^{\mathrm{b}}$ & & \\
\hline
\end{tabular}

${ }^{\mathrm{a} S e v e r e ~ d y s p l a s i a ~ g r o u p ~ v s . ~ m i l d ~ d y s p l a s i a ~ g r o u p, ~} \mathrm{P}<0.01 .{ }^{\mathrm{b}} \mathrm{Carcinoma}$ group vs. severe dysplasia group, $\mathrm{P}<0.01$. hTERT, human telomerase reverse transcriptase; FI, fluorescence index; F, F-value.
Table III. Detection of telomerase activity in various esophageal tissues.

\begin{tabular}{lcrcc}
\hline & \multicolumn{4}{c}{ Telomerase activity } \\
\cline { 3 - 5 } Group & $\mathrm{n}$ & $\begin{array}{c}\text { Positive } \\
\text { no. }\end{array}$ & Rate & A-value \\
\hline Carcinoma group & 50 & 42 & $84^{\mathrm{a}}$ & $1.457 \pm 0.838^{\mathrm{a}, \mathrm{b}}$ \\
Dysplasia group & 50 & 31 & $62^{\mathrm{a}}$ & $0.429 \pm 0.346^{\mathrm{a}}$ \\
Normal group & 50 & 3 & 6 & $0.073 \pm 0.039$ \\
\hline
\end{tabular}

${ }^{\text {a }} \mathrm{P}<0.05$, compared with the normal group; ${ }^{\text {}} \mathrm{P}<0.05$, compared with the dysplasia group.
A
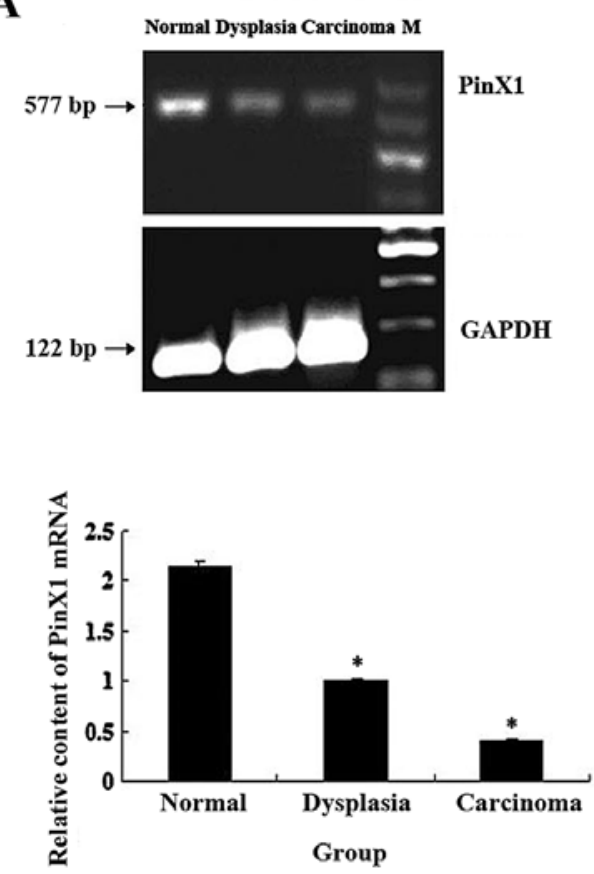

B
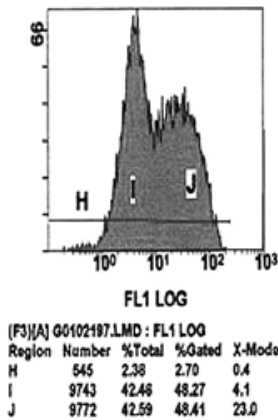

Normal group
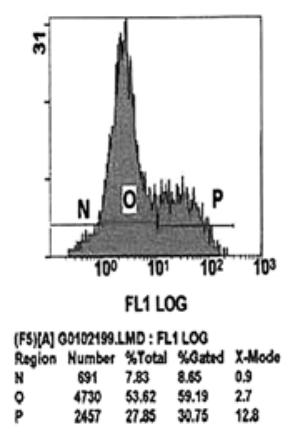

Dysplasia group

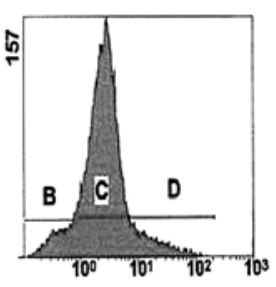

FL1 LOG

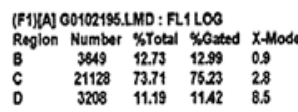

Carcinoma group

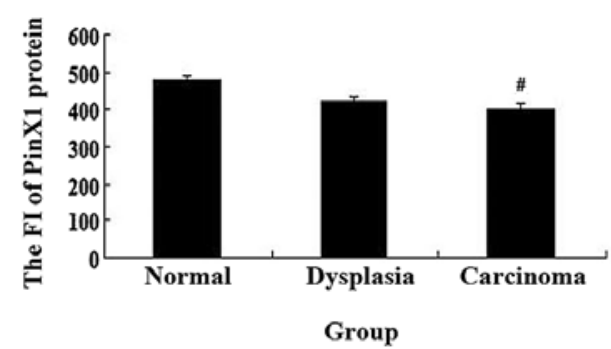

Figure 2. Decrease of Pin2/TRF1 interacting protein X1 (PinX1) mRNA and protein in esophageal squamous cell carcinoma. (A) RT-PCR of PinX1 mRNA in esophageal tissue. ${ }^{*} \mathrm{P}<0.01$ vs. normal group. (B) FCM of PinX1 protein, ${ }^{*} \mathrm{P}<0.05$ vs. normal group; ${ }^{\text {}} \mathrm{P}<0.05$ vs. dysplasia group.

There was a significant negative correlation between telomerase activity expression and PinX1 protein expression $\left(\mathrm{r}_{\mathrm{s}}=-0.883, \mathrm{P}=0.000\right)$.

Overexpression of PinX1 in telomerase activity, cell proliferation and apoptosis in Ecal09 cells. To investigate the effect of PinX1 on telomerase activity and cell growth, Eca109 cells were transfected with expression vector for PinX1 (pCR3.1/PinX1) or control vector (pCR3.1). The expression of PinX1 protein was 4.5-fold greater than that of the control group (Fig. 3A). We further examined the effect of PinX1 on the telomerase activity by TRAP-PCR, cell proliferation and apoptosis by FCM. In Eca109 cells, PinX1 overexpression decreased Eca109 cell growth (Fig. 3B) and blocked cells into the G0/G1 stage (Fig. 3C) (Table VI). The apoptosis rate was higher in PinX1-transfected Eca109 than in PinX1-untransfected cells or cells transfected with void vectors only by FCM (Fig. 3D) (Table VI).
The expression of telomerase activity was lower in PinX1-transfected Eca109 than in PinX1-untransfected cells or cells transfected with vectors only $(\mathrm{P}<0.05$, Table VII).

There was a significant positive correlation between telomerase activity expression and PI expression $\left(r_{s}=0.451\right.$, $\mathrm{P}=0.000)$.

\section{Discussion}

Telomere shortening results in chromosomal instability which, in the absence of normal cellular senescence processes, can lead to cancer development (27). In the present study, we collected esophageal tissue in a high incidence area of China in order to detect the length of telomere. The results showed that telomere shortening occurred in the carcinogenesis of esophageal epithelial cells, which indicated that telomere shortening is an important event in the carcinogenesis of esophageal squamous epithelial cells. 
Table IV. Relationship between telomerase activity and clinicopathological features in human esophageal squamous cell carcinomas.

\begin{tabular}{|c|c|c|c|c|c|}
\hline \multirow[b]{2}{*}{ Clinicopathological feature } & \multirow[b]{2}{*}{$\mathrm{n}$} & \multicolumn{3}{|c|}{ Telomerase activity } & \multirow[b]{2}{*}{ P-value } \\
\hline & & Positive no. & Rate $(\%)$ & A-value & \\
\hline \multicolumn{6}{|l|}{ Gender } \\
\hline Male & 35 & 30 & 85.71 & $1.253 \pm 0.672$ & \multirow[t]{2}{*}{$>0.05$} \\
\hline Female & 15 & 12 & 80 & $1.702 \pm 0.823$ & \\
\hline \multicolumn{6}{|l|}{ Age (years) } \\
\hline$\leq 60$ & 36 & 30 & 83.33 & $1.465 \pm 0.672$ & \multirow[t]{2}{*}{$>0.05$} \\
\hline$>60$ & 14 & 12 & 85.71 & $1.797 \pm 0.952$ & \\
\hline \multicolumn{6}{|l|}{ Depth of invasion } \\
\hline Fibrous membrane & 16 & 13 & 81.25 & $1.467 \pm 0.923$ & \multirow[t]{2}{*}{$>0.05$} \\
\hline $\begin{array}{l}\text { Fibrous membrane } \\
\text { Untouched }\end{array}$ & 34 & 29 & 85.29 & $1.534 \pm 0.782$ & \\
\hline \multicolumn{6}{|l|}{ Grade } \\
\hline Well/moderately differentiated & 39 & 32 & 82.05 & $1.163 \pm 0.438$ & \multirow[t]{2}{*}{$<0.05$} \\
\hline Poorly differentiated & 11 & 10 & 90.91 & $2.235 \pm 0.814^{\mathrm{a}}$ & \\
\hline \multicolumn{6}{|l|}{ Lymph node metastasis } \\
\hline Positive & 17 & 16 & 94.12 & $1.917 \pm 0.814^{\mathrm{a}}$ & \multirow[t]{2}{*}{$<0.05$} \\
\hline Negative & 33 & 26 & 78.79 & $1.097 \pm 0.865$ & \\
\hline
\end{tabular}

Table V. The relationship between PinX1 protein expression and clinicopathological features in ESCC.

\begin{tabular}{lccc}
\hline $\begin{array}{l}\text { Clinicopathological } \\
\text { feature }\end{array}$ & $\mathrm{n}$ & PinX1 protein & P-value \\
\hline Age (years) & & & \\
$\quad \leq 60$ & 30 & $445.88 \pm 22.13$ & \\
$>60$ & 20 & $443.38 \pm 23.95$ & 0.63 \\
Gender & & & \\
$\quad$ Male & 35 & $442.70 \pm 22.57$ & \\
Female & 15 & $449.39 \pm 23.18$ & 0.23 \\
Differentiation grade & & & \\
$\quad$ Well/moderately & 39 & $441.04 \pm 22.02$ & \\
$\quad$ Poorly & 11 & $455.33 \pm 22.22$ & 0.01 \\
Depth of invasion & & & \\
Fibrous membrane & 34 & $448.80 \pm 22.76$ & \\
Fibrous membrane & 16 & $436.45 \pm 21.02$ & $0.02^{\mathrm{a}}$ \\
$\quad$ Untouched & & & \\
Lymph node metastasis & & & \\
Positive & 17 & $453.91 \pm 19.78$ & \\
Negative & 33 & $440.14 \pm 23.04$ & 0.01 \\
\hline
\end{tabular}

PinX1, Pin2/TRF1 interacting protein X1; ESCC, esophageal squamous cell carcinoma.

Telomerase is a special reverse transcriptase that is composed of RNA and protein and regulates the length of telomere. hTERT is the key component in telomerase and plays an important role in genetic stability and maintenance of
Table VI. Changes of cell cycle distribution, PI and apoptotic rate in different groups.

\begin{tabular}{lccc}
\hline Cell & G0/G1 & PI & $\begin{array}{c}\text { Apoptotic } \\
\text { rate }\end{array}$ \\
\hline Eca109 & $53.14 \pm 4.83$ & $33.17 \pm 0.47$ & $0.27 \pm 0.18$ \\
Eca109/PCDNA3.1 & $47.27 \pm 3.73$ & $35.64 \pm 0.65$ & $3.40 \pm 1.09$ \\
Eca109/PinX1 & $70.58 \pm 5.26^{\mathrm{a}}$ & $13.58 \pm 0.59^{\mathrm{a}}$ & $23.28 \pm 5.73^{\mathrm{a}}$ \\
\hline
\end{tabular}

${ }^{\mathrm{a}} \mathrm{P}<0.05$ vs. Eca109 cells and Eca109/PCDNA3.1 cells. PI, proliferation index; PinX1, Pin2/TRF1 interacting protein X1.

Table VII. Detection of telomerase activity in various cells.

\begin{tabular}{llcr}
\hline Cell & A-value & F & P-value \\
\hline Eca109 & $2.446 \pm 0.652$ & & \\
Eca109/PCDNA3.1 & $2.137 \pm 0.475$ & & \\
Eca109/PinX1 & $0.874 \pm 0.439^{\mathrm{a}}$ & 163.25 & 0.000 \\
\hline
\end{tabular}

${ }^{\mathrm{a} P}<0.05$ vs. Eca109 and Eca109/ PCDNA3.1 cells. PinX1, Pin2/ TRF1 interacting protein X1; F, F-value.

chromosomes. Several studies have indicated that telomerase is only slightly expressed in normal cells, but its expression and activity are enhanced in most immortalized tumor cells $(28,29)$. Previous studies have verified that telomerase is significantly related to the incidence of human malignant tumors (30). Enhancement of its activity is the power source 
PinX1 (41 kDa)

$\beta$-actin (42 kDa)

B

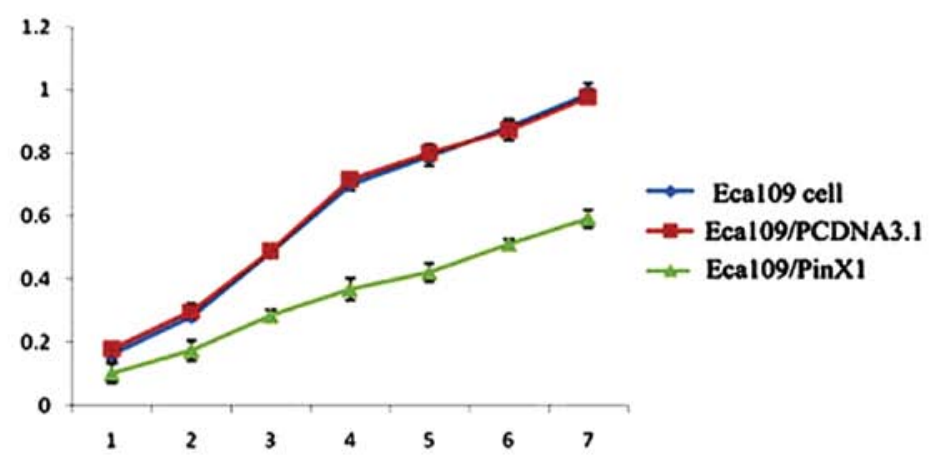

C
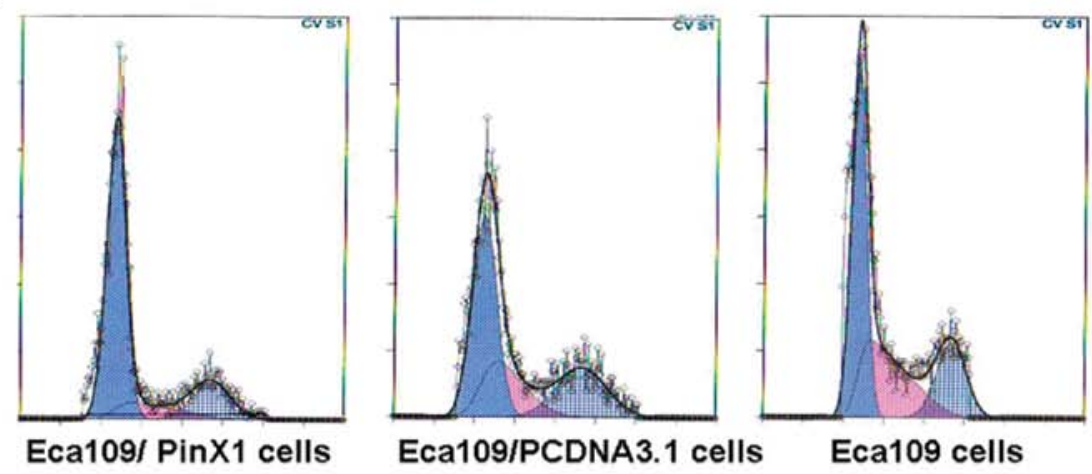

D
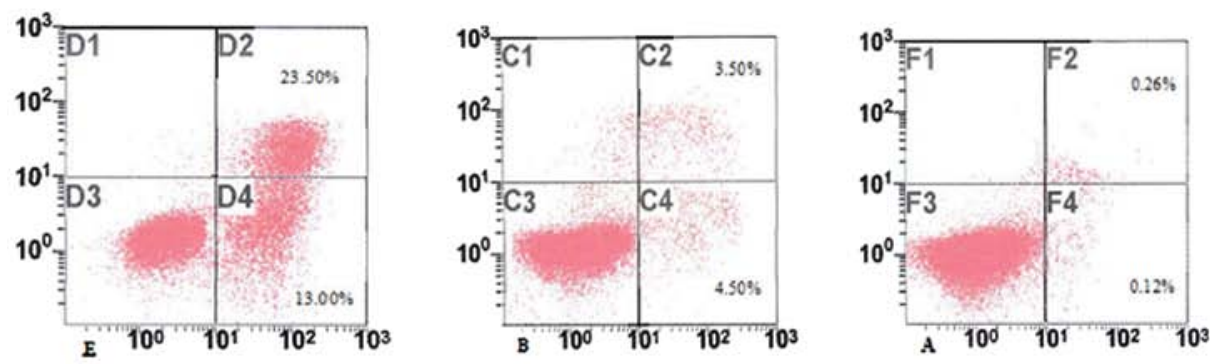

Eca109/ PinX1 cells

\section{Eca109/PCDNA3.1 cells}

\section{Eca109 cells}

Figure 3. Overexpression of Pin2/TRF1 interacting protein X1 (PinX1) inhibits cell proliferation and induces cell apoptosis in Eca109 cells. (A) Detection of PinX1 protein by western blot analysis. (B) Cell growth by MTT. (C) Cell cycle distribution by FCM. (D) Cell apoptosis by FCM.

of constantly increased proliferation, invasion and metastasis of tumor cells. Therefore, downregulation of telomerase activity in tumor cells may be one of the important therapeutic measures to inhibit tumor growth. Enhanced hTERT/CMV promoter can reduce telomerase activity, eventually leading to the death of tumor cells (31). The PinX1 gene is located on chromosome 8p22-23 region and can attenuate telomerase activity, inhibit growth of tumor cells and induce apoptosis. Lack of endogenous PinX1 leads to increased telomerase activity and tumorigenicity in nude mice. Therefore, PinX1 is considered a telomerase inhibitor and tumor suppressor.
Our study indicated that increase of telomerase activity and hTERT protein followed by decrease of PinX1 mRNA and protein occurred in the carcinogenesis of esophageal epithelial cells and there was a significantly negative correlation between PinX1 and tumor grade, depth of infiltration and lymph node metastasis. From these results, we deduced that the PinX1 gene may be used as one of the molecular markers to determine the malignant degree, metastasis potency and predicting progression of ESCC.

However, the mechanism of PinX1 functioning in tumor cells has yet to be fully elucidated. Some studies indicate that 
the PinX1 gene can inhibit telomerase activity and induce cell apoptosis and expression of PinX1 is negatively correlated with hTERT expression and telomerase activity in tumor cells. For example, Lai et al (32) reported that overexpression of PinX1 decreased hTERT mRNA by $21 \%$, reduced telomerase activity, inhibited cell growth, migration and wound healing ability, arrested cells in the G0/G1 phase, and increased AI. Zhang et al (33) reported that silencing the PinX1 gene using short hairpin RNA can lead to significant shortening of telomere and growth inhibition of telomerase-positive tumor cells, but not telomerase-negative tumor cells, indicating PinX1 affects telomere length and tumorigenicity through regulating telomerase activity. Wang et al (34) constructed and transfected PinX1 and PinX1-siRNA eukaryotic expression vectors into gastric cancer cells and found that downregulation of PinX1 significantly enhanced telomerase activity compared with cells transfected with PinX1 vector, indicating that PinX1 is a telomerase inhibitor and inhibits tumorigenesis and development possibly through the telomerase/telomere pathway. To better understand the role of PinX1 in esophageal cancer cells, we also successfully established overexpression of PinX1, the transfection of which significantly increased endogenous PinX1 protein in Eca109 cells. Moreover, PinX1 overexpression inhibited telomerase activity and Eca109 cell growth, and blocked cells into the G0/G1 stage, induced apoptosis, suggesting that PinX1 is a telomerase inhibitor and inhibits tumorigenesis and development possibly through the telomerase/telomere pathway.

Zhou and Lu (35) considered that PinX1 inhibits telomerase activity by binding to hTERT through its TID domain, which consequently results in telomere shortening, cell senescence and increase of tumorigenicity in nude mice. Banik and Counter (36) showed that inhibition of telomerase activity by PinX1 requires its binding to both hTERT and hTR. In the present study, we found that there were significantly negative correlations between the expression of PinX1 and hTERT, telomerase activity in carcinogenesis of esophageal epithelial cells, respectively, thus we considered that the inhibition of PinX1 in telomerase activity may contribute to downregulation of hTERT. However, the precise mechanism requires further examination.

In summary, our data demonstrate that the length shortening of telomere is an important characteristic in the carcinogenesis of esophageal epithelial cells, followed by increase of telomerase activity and downregulation of PinX1. Overexpression of PinX1 blocked Eca109 cell proliferation and induced cell apoptosis by downregulating the telomerase activity. However, further studies are required to examine the precise role of PinX1 in telomerase activity in the pathogenesis of esophageal cancer.

\section{Acknowledgements}

This study was supported by the Hebei Natural Science Foundation (H2012206107, 062611136D-5).

\section{References}

1. Risques RA, Vaughan TL, Li X, et al: Leukocyte telomere length predicts cancer risk in Barrett's esophagus. Cancer Epidemiol Biomarkers Prev 16: 2649-2655, 2007.
2. Xing J, Ajani JA, Chen M, et al: Constitutive short telomere length of chromosome $17 p$ and $12 q$ but not $11 q$ and $2 p$ is associated with an increased risk for esophageal cancer. Cancer Prev Res (Phila) 2: 459-465, 2009.

3. Cohen SB, Graham ME, Lovrecz GO, et al: Protein composition of catalytically active human telomerase from immortal cells. Science 315: 1850-1853, 2007.

4. Pao CC, Tseng CJ, Lin CY, et al: Differential expression of telomerase activity in human cervical cancer and cervical intraepithelial neoplasia lesions. J Clin Oncol 15: 1932-1937, 1997.

5. Anderson S, Shera K, Ihle J, et al: Telomerase activation in cervical cancer. Am J Pathol 151: 25-31, 1997.

6. Heselmeyer-Haddad K, Janz V, Castle PE, et al: Detection of genomic amplification of the human telomerase gene (TERC) in cytologic specimens as a genetic test for the diagnosis of cervical dysplasia. Am J Pathol 163: 1405-1416, 2003.

7. Heselmeyer-Haddad K, Sommerfeld K, White NM, et al: Genomic amplification of the human telomerase gene (TERC) in pap smears predicts the development of cervical cancer. Am J Pathol 166: 1229-1238, 2005.

8. Andersson S, Wallin KL, Hellström AC, et al: Frequent gain of the human telomerase gene TERC at $3 \mathrm{q} 26$ in cervical adenocarcinomas. Br J Cancer 95: 331-338, 2006

9. Hopman A, Theelen W, Hommelberg P, et al: Genomic integration of oncogenic HPV and gain of the human telomerase gene TERC at $3 q 26$ are strongly associated events in the progression of uterine cervical dysplasia to invasive cancer. J Pathol 210: 412-419, 2006.

10. Sokolova I, Algeciras-Schimnich A, Song M, et al: Chromosomal biomarkers for detection of human papillomavirus associated genomic instability in epithelial cells of cervical cytology specimens. J Mol Diagn 9: 604-611, 2007.

11. Caraway NP, Khanna A, Dawlett M, et al: Gain of the 3q26 region in cervicovaginal liquid-based pap preparations is associated with squamous intraepithelial lesions and squamous cell carcinoma. Gynecol Oncol 110: 37-42, 2008.

12. Hashimoto Y, Murakami Y, Uemura K, et al: Detection of human telomerase reverse transcriptase (hTERT) expression in tissue and pancreatic juice from pancreatic cancer. Surgery 143: $113-125,2008$.

13. Saha B, Chaiwun B, Tsao-Wei DD, et al: Telomerase and markers of cellular proliferation are associated with the progression of cervical intraepithelial neoplasia lesions. Int J Gynecol Pathol 26: 214-222, 2007.

14. Branca M, Giorgi C, Ciotti M, et al: Upregulation of telomerase (hTERT) is related to the grade of cervical intraepithelial neoplasia, but is not an independent predictor of high-risk human papillomavirus, virus persistence, or disease outcome in cervical cancer. Diagn Cytopathol 34: 739-748, 2006.

15. Kondo T, Oue N, Mitani Y, et al: Loss of heterozygosity and histone hypoacetylation of the PINX1 gene are associated with reduced expression in gastric carcinoma. Oncogene 24: 157-164, 2005.

16. Ma Y, Wu L, Liu C, et al: The correlation of genetic instability of PINX1 gene to clinico-pathological features of gastric cancer in the Chinese population. J Cancer Res Clin Oncol 135: 431-437, 2009.

17. Liao C, Zhao MJ, Zhao J, et al: Over-expression of LPTS-L in hepatocellular carcinoma cell line SMMC-7721 induces crisis. World J Gastroenterol 8: 1050-1052, 2002.

18. Liao C, Zhao M, Song H, et al: Identification of the gene for a novel liver-related putative tumor suppressor at a high-frequency loss of heterozygosity region of chromosome $8 \mathrm{p} 23$ in human hepatocellular carcinoma. Hepatology 32: 721-727, 2000.

19. Sun J, Huang H, Zhu Y, et al: The expression of telomeric proteins and their probable regulation of telomerase during the differentiation of all-trans-retinoic acid-responsive and -resistant acute promyelocytic leukemia cells. Int J Hematol 82: 215-223, 2005.

20. Sun J, Tan YM, Huang H, et al: Expression of telomerase inhibitor Pinx1 in leukemia cells and its correlation with telomerase activity. Chinese J Pathophysiology 22: 1725-1728, 2006.

21. Hawkins GA, Chang BL, Zheng SL, et al: Mutational analysis of PINX1 in hereditary prostate cancer. Prostate 60: 298-302, 2004.

22. Akiyama Y, Maesawa C, Wada K, et al: Human PinX1, a potent telomerase inhibitor, is not involved in human gastrointestinal tract carcinoma. Oncol Rep 11: 871-874, 2004.

23. Chang Q, Pang JC, Li J, et al: Molecular analysis of PinX1 in medulloblastomas. Int J Cancer 109: 309-314, 2004. 
24. Yuan K,Li N, Jiang K, et al: PinX1 is a novel microtubule-binding protein essential for accurate chromosome segregation. J Biol Chem 284: 23072-23082, 2009.

25. Hao J, Zhu L, Zhao S, et al: PTEN ameliorates high glucose-induced lipid deposits through regulating SREBP-1/ FASN/ACC pathway in renal proximal tubular cells. Exp Cell Res 317: 1629-1639, 2011.

26. Feng X, Hao J, Liu Q, et al: HMGB1 mediates IFN- $\gamma$-induced cell proliferation in MMC cells through regulation of cyclin D1/ CDK4/p16 pathway. J Cell Biochem 113: 2009-2019, 2012.

27. Wentzensen IM, Mirabello L, Pfeiffer RM and Savage SA: The association of telomere length and cancer: a meta-analysis. Cancer Epidemiol Biomarkers Prev 20: 1238-1250, 2011.

28. Klingelhutz AJ: The roles of telomeres and telomerase in cellular immortalization and the development of cancer. Anticancer Res 19: 4823-4830, 1999.

29. Wang XW, Xiao J, Zhao S, et al: Expression of telomerase subunits and its relationship with telomerase activity in nasopharyngeal carcinoma. Zhonghua Yi Xue Za Zhi 81: 553-556, 2001 (In Chinese)

30. Liu H, Liu S, Wang $\mathrm{H}$, et al: Genomic amplification of the human telomerase gene (hTERC) associated with human papillomavirus is related to the progression of uterine cervical dysplasia to invasive cancer. Diagnostic Pathol 7: 147, 2012.
31. Shen CX, Wen Z, Qian YH, et al: Targeted gene therapy of nasopharyngeal cancer in vitro and in vivo by enhanced thymidine kinase expression driven by human TERT promoter and CMV enhancer. J Exp Clin Cancer Res 29: 94, 2010.

32. Lai XF, Shen CX, Wen Z, et al: PinX1 regulation of telomerase activity and apoptosis in nasopharyngeal carcinoma cells. J Exp Clin Cancer Res 31: 12, 2012.

33. Zhang B, Bai YX, Ma HH, et al: Silencing PinX1 compromises telomere length maintenance as well as tumorigenicity in telomerase-positive human cancer cells. Cancer Res 69: 75-83, 2009.

34. Wang HB, Wang XW, Zhou G, et al: PinX1 inhibits telomerase activity in gastric cancer cells through Mad1/c-Myc pathway. J Gastrointest Surg 14: 1227-1234, 2010.

35. Zhou XZ and Lu KP: The Pin2/TRF1-interacting protein PinX1 is a potent telomerase inhibitor. Cell 107: 347-359, 2001.

36. Banik SS and Counter CM: Characterization of interactions between PinX1 and human telomerase subunits hTERT and hTR. J Biol Chem 279: 51745-51748, 2004. 